\title{
Implementation of Tobacco Control Policies in Bangladesh: A Political Economy Analysis
}

\author{
Md Mahmudul Hoque ${ }^{1}$ \& Riffat Ara Zannat Tama² \\ ${ }^{1}$ University of Sussex, Brighton, UK \\ ${ }^{2}$ Department of Agricultural Economics, Bangladesh Agricultural University, Mymensingh, Bangladesh \\ Correspondence: Md Mahmudul Hoque, University of Sussex, Brighton, UK. E-mail: mh496@sussex.ac.uk; \\ mhmoni24@gmail.com
}

$\begin{array}{lc}\text { Received: August 4, } 2021 & \text { Accepted: August 25, } 2021 \quad \text { Online Published: August 26, } 2021 \\ \text { doi:10.5539/par.v10n2p36 } & \text { URL: http://dx.doi.org/10.5539/par.v10n2p36 }\end{array}$

\begin{abstract}
After ratifying the Framework Convention for Tobacco Control in 2004, Bangladesh enacted anti-tobacco laws, policies, and administrative measures. Evidence suggests that the progress so far has not been significant, and Bangladesh will most likely fail to meet its target to become tobacco-free by 2040. This study undertakes a national-level political economy analysis to explore the dynamics that affect the processes of required tobacco policy reforms and implementation. Based on a desk review of pertinent pieces of literature and key informant interviews, this research examines the political behavior of key individuals, institutional reform initiatives, and the government's commitment to the tobacco control agenda. The findings indicate that the political will of becoming tobacco-free is explicitly present in key narratives. However, intra-government conflict of interests and incentives, the skewed commitment of government bodies, state-business nexus, incapacity of vital organizations, and the dubious role of key individuals and committees fail to translate this will into active implementation. The article concludes that the idea of tobacco control remains a strategic accommodation, and its implementation requires genuine commitment and wider public support. The government must confer adequate authority and resources to the national tobacco control cell and call for agencies to convene to the common of creating a tobacco-free Bangladesh.
\end{abstract}

Keywords: tobacco control, Bangladesh, political economy analysis, anti-tobacco policy, tobacco-free

\section{Introduction}

Bangladesh is the first country to sign the World Health Organization's Framework Convention on Tobacco Control (FCTC). The government endorsed the Convention in 2003, and became the first party to ratify the treaty in 2004 (Hoque, 2016; Marquez et al., 2019; A. Rahman et al., 2017). To fulfill its commitment to this widely international Convention, the government immediately enacted the Smoking and Tobacco Products Usage (Control) Act 2005, aiming to control the production, promotion, and consumption of tobacco (NTCC, 2013). This formalization of tobacco control policies in Bangladesh was a product of a concerted effort from national and international organizations. Efroymson and Ahmed (2003) argue that such a strong policy response was unexpected since tobacco was seen as a relatively minor issue until the 1990s. In the $90 \mathrm{~s}$, a few isolated civil society groups with no real power took on tobacco control in Bangladesh. This movement led the shift of focus from health to wider socio-political implications of tobacco. In 1999 the landmark "Voyage of Discovery" court petition" underpinned the movement of tobacco control in Bangladesh when the High Court delivered its judgment asking the government to undertake control measures on tobacco (Efroymson, 2000). The momentum gained by tobacco control advocacy organizations led to the country's participation in FCTC in 2003.

In the last two decades, the socio-political and economic scenario of Bangladesh has changed significantly. Since the current government came to power in 2009, the country's economy has attained remarkable economic growth (Islam, 2021; Salma et al., 2020; Tama et al., 2018). Despite some critical national and international issues, the achievements in social development indicators, especially in poverty reduction, have also been astonishingly significant (Barai, 2020; Hoque, 2021; M. Mahmud et al., 2018; Tama et al., 2021). The country, currently being among the fastest growing economies in the world, is set to graduate from the UN's Least Developed Countries (LDC) list in 2026 (Hoque, 2018b; Sarker et al., 2020; World Bank, 2021). Meanwhile, tobacco control policies and measures have also become stronger and stricter. In 2009, the National Tobacco Control Cell was established 
as a separate institution under the Ministry of Health and Family Welfare to enforce tobacco control laws and undertake measures to protect people from tobacco's devastating and harmful effects. Subsequently, the 2005 Tobacco Control Law was revised in 2013, and Tobacco Control Rules 2015 was notified to showcase the government's commitment to its vision of creating a tobacco-free ${ }^{2}$ country (Choudhury, 2017; Shikha \& Sultana, 2019). With that mission, the government, in 2007 , set out a target to reduce tobacco use by $1 \%$ every year (Choudhury, 2017). Several significant policy changes were enacted to support the state campaign against widespread tobacco use. This included putting bans and restrictions on the advertisements of tobacco products, prohibiting smoking in public places and sales to minors, imposing additional taxes on tobacco products, and making graphic health warnings on smoke packs mandatory.

Two interdependent questions remain pertinent - (i) has tobacco use decreased? (ii) has tobacco control been achieved in Bangladesh? Evidence suggests that the answer to the first question is "yes, but not as much as expected", while the answer to the second question remains critically complicated and multifaceted. The Global Adult Tobacco Survey (GATS) is a nationally representative household cross-sectional data survey which was launched in 2007 to generate data for monitoring adult tobacco use in more than 30 FCTC member countries. The 2017 GATS Bangladesh Survey report reveals that notable progress has been made in reducing the exposure to secondhand smoke, ceasing promotional activities, and promoting anti-tobacco media campaigns (BBS \& NTCC, 2019). A comparison between the last two GATS in Bangladesh shows that tobacco use (both smoking and nonsmoking) significantly decreased among adults (aged 15 or above) from $43.3 \%$ in 2009 to $35.3 \%$ in 2017 (BBS, 2018). However, this $35.3 \%$ still constitutes 37.8 million adults, which remains a big concern, especially considering the high population density of the country. Delving deep into the data, Ahmed (2021) shows that the cigarette smoking prevalence among adults have in fact increased. He argues that although the percentage remained almost the same in 2017 compared to what it was in 2009, the actual number of adult cigarette smokers have gone up by 1.5 million. Moreover, tobacco use is also prevalent among young children aged below 15 . The 2013 Global Youth Tobacco Survey (GYTS) shows that 6.9\% school going children (ages 13-15) use tobacco (in any form) in Bangladesh (WHO, 2015).

Several studies point out that the tax imposed on tobacco products is inadequate to be effective in reducing its use since it fails to counteract the effect of steady growth in per capita income in the country (N. Ahmed, 2021; Marquez et al., 2019; Nargis et al., 2019, 2020). Marquez et al. (2019) reports that areas of land used for tobacco growing in Bangladesh has been shrinking steadily for most of the past three decades, before rising sharply again in 2010. Available evidence indicates an inconclusive result for the manufacture of tobacco products, they add. However, the shift of tobacco consumption from $b i d i^{3}$ and smokeless tobacco use to cigarette smoking is a concern for policymakers and activists alike. The prevalence rate of adolescent tobacco use and second-hand smoking is still unsatisfactory (Ahammed et al., 2021; Shah et al., 2019). In a nutshell, the country has so far failed to achieve its targets and the vision of being tobacco-free by 2040 is very opaque, and unlikely to be met. In this article, we started by asking why, despite having control policies in place, Bangladesh struggles to achieve its targets for tobacco control. It remains puzzling why the outcomes of tobacco control policies in Bangladesh are so diverse and explicitly aimless. From a governance and public administration perspective, we focus on the dynamics within the government structures and institutions to explain this puzzle. This paper is organized as follows. The subsequent literature review section identifies the rationale of this study, followed by sections defining the scope and methodology. The following sections illustrate the findings and analysis before the conclusions.

\section{Literature Review}

As a contested and cross-cutting issue, tobacco control draws a variety of perspectives in its academic inquiry. However, the importance of political economy as a lens to study the politics of tobacco control both at international and national levels has been critically recognized. Jarman (2015) examined various political conflicts and competing interests regarding tobacco control in global trading systems, and Cairney et al. (2012) analyzed tobacco control policies across all regions to understand how power and politics influence the transfer of policy and governance of tobacco control across the world. Both analyses show that the role of ideas, institutions, and interests are fundamental to understand the change and diffusion of tobacco control policies across nations. Bump et al. (2009) also reviewed the literature on tobacco control in low and middle-income countries (LMICs) and found that very few pieces had utilized political economy as a formal analytical methodology. Bump and Reich (2013) conducted a similar review illustrating that the literature largely focused on the critical aspects of the tobacco epidemic, while the political and economic dynamics of policy adoption and implementation in LMICs were not adequately explored. They differentiate political economy analysis from the dominant public health approaches to create a better understanding of the execution of tobacco control policies in developing countries like Bangladesh.

Empirical studies of national level tobacco control in Bangladesh largely focuses on the economics, trade, and 
taxation policies of tobacco (N. Ahmed et al., 2019; S. Ahmed et al., 2019; Barkat et al., 2012; Nargis et al., 2020; H. Rahman \& Parvin, 2017). These studies recommend heavy taxation on tobacco, especially on smoking products, and reduction of production and supply. Another dominant perspective of tobacco control concerns public health, and empirical studies emphasize the harmful and deadly effects of various types of tobacco products on human health (N. Ahmed et al., 2019; Driezen et al., 2016; Wu et al., 2013). Furthermore, tobacco-related studies highlight both national and local issues. National issues include interference of the tobacco industry and loopholes in government policies and strategies (Banu, 2017; Rahman et al., 2017). Local issues include child employment, environmental degradation, and tobacco farming (Hossain, 2013; Hussain et al., 2020; PRI, 2016; Talukder et al., 2020). A few studies have also illustrated issues with tobacco industries' governance, social responsibilities, and employment (Genilo \& Sharif, 2015; Mondol et al., 2021; Rasheed \& Sinha, 2012). Faruque et al. (2020, p. 2) note that although tobacco control has been an obvious government priority, 'adoption and application of a fully functional and effective measure have been constrained by the powerful lobby of the financially strong tobacco companies.' Advocacy organizations mainly depend on these discourses while demanding for stronger tobacco control policy mechanisms. Reports and voices raised in advocacy campaign events indicate that common interests of tobacco businesses and a faction of public policy makers hinder tougher tobacco control measures in the country.

The body of scientific knowledge concerning tobacco control in Bangladesh conveys three critical messages. First, the voices of tobacco companies are largely missing in the literature. It could be that the companies do not want to speak to the researchers, or also the other way around. Second, there is hardly any empirical study that has purely focused on the political economy of tobacco control in Bangladesh. Barkat et al., (2008) studied the political economy of tobacco cultivation and processing, and critically examined the role of tobacco businesses in organizing contract farming with rural farmers. Third, the current body of literature do not provide any in-depth knowledge to explain the slow progress of tobacco control in the country. This study illustrates the national level politics of tobacco control in Bangladesh by analyzing the interactions of political and economic interests of key stakeholders.

\section{Definitions and Methods}

\subsection{Defining Political Economy Analysis}

Although political economy has diverse meanings and remains a hard-to-define concept, it is broadly understood as the interrelationship between economics and politics (Bump \& Reich, 2013; Hoque \& Tama, 2020; Weingast \& Wittman, 2009, 2011). Political economy analysis (PEA) informs us why a supposedly good policy solution cannot be implemented in the context of a given national or local socio-political settlement (FAO, 2017). Hudson and Leftwich $(2014$, p. 6) notes that contemporary political economy analysis focuses on how 'interests, incentives and institutions shape and explain both how agents behave and the political processes and practices that affect development outcomes.' This analysis is particularly useful to recognize the drivers of political behavior, to explain the progress of policies and programmes, to identify winners and losers in the game, and to explore the implications of development programmes (Booth \& Cammack, 2009). In recent times, PEA has secured wide acceptance among scholars across the social sciences since it guides practitioners and policy makers to develop more effective strategies to change the political feasibility of desired reforms (Bump \& Reich, 2013; Sparkes et al., 2019). Several recent national level studies have also used PEA to explore the politics of tobacco control. For instance, Chantornvong and McCargo (2001) applied PEA to identify powerful forces that supported and opposed the development of anti-tobacco campaigns in Thailand. Rosser's (2015) analysis of competing political interests in tobacco control policies in Indonesia is also largely based on PEA.

However, being inspired from Bump \& Reich (2013), this research work is intended to explore the politics of tobacco control by investigating pertinent political and economic dimensions of policy adoption, implementation, and enforcement in Bangladesh. For this purpose, we adopt the underlying features put forward by Pettit and Acosta (2014) who observe that although the methodology of PEA has varied features, its principal focus remains on actors, networks, institutions, and their contending interests. Reviewing pertinent theoretical literature, Pettit and Acosta (2014) categorized the key elements of national level PEA into three main features - (i) Institution matters, (ii) Individual matters, and (iii) commitment matters. First, both formal and informal institutions being embedded in social and historic contexts shape behavior and reproduce power asymmetries. These institutions set the "rules of the game" in a political and economic context. Second, focusing on individuals (or a group of individuals with similar interests) is essential to explore the best interests (material or other benefits), given their socioeconomic and legal constraints. Third, paying attention to commitment in recognizing the motivations of key stakeholders to cooperate (or not) over time is also critical. The commitment can be reflected in decisions and enforced through formal and informal institutions (Hoque, 2018a). 
Haider and Sumedh (2010) note that PEA can encompass three level of analysis, namely country level (macro), policy implementation (meso), and policy impact (micro). We place this analysis at the meso level since it involves the processes, rules, and motivations influencing implementation of tobacco control policies in Bangladesh. Therefore, as Haider and Sumedh (2010, p. 26) suggest, this study entails the analysis of interests and influence of actors (stakeholder analysis), and the rules and commitments governing the implementation of policies (institutional analysis).

\subsection{Methods}

The premise of this study is set primarily by the review of the literature. Considering the complexity of the issue and nature of intended PEA, we undertook a qualitative method to allow ourselves to navigate and explore the political and economic dynamics within the domain of tobacco control implementation in Bangladesh. This qualitative study was conducted combining both primary and secondary research. Apart from reviewing peerreviewed published articles, we also performed a desk review of various kinds of published pieces including reports, policy documents, opinions, interviews, commentaries, and website content. We particularly paid attention to the content of the policy papers available on the respective government websites. Recent and relevant items were carefully studied and examined. From the secondary research (conducted from January 2021 to April 2021), we identified the key stakeholders at the national level (actors and organizations) inside the domain of tobacco control in Bangladesh. Preparing a list of formal institutions was helpful to identify the responsibilities of these stakeholders. We classified the stakeholders into three broad categories - state, market, and society. We conducted in-depth interviews with several key informants from each of these categories. Key informant interviews (KIIs) is a widely-used qualitative method to explore the deep dynamics in policy-focus research (Lokot, 2021). A total of 12 KIIs were conducted online using digital communication platforms. Prior consent was obtained through email. We completed the interviews during June-July 2021. Key informants included activists, government employees, ex-employees of tobacco companies, lawyers, journalists, executive magistrates, and policymakers. Purposive and snowball tactics guided the sample selection process.

Although ensuring equal representation was attempted, no current tobacco business employees accepted our invitations. We opted to interview two ex-employees of tobacco companies that currently operate at the national level. Open-ended questions were prepared based on the review of literature and documents. These questions guided the conversations between us and the informants. Although there was an interview guide, the interviews were conducted conversationally to provide the informants with ease and confidence. This strategy helped us to navigate through the rugged terrains of this complicated public health and governance issue and critically connect various dots. The medium of communication in these KIIs was Bangla.

\section{Findings and Discussion}

The interview scripts were transcribed and translated by the authors before employing a thematic analysis technique to analyze the content. The analysis was conducted in accordance with the components of PEA discussed in the previous section. The themes were broadly categorized in line with the three key aspects of PEA. In the following section, we illustrate the public administration to tobacco control in Bangladesh to highlight the role of various government organizations and to explain how the implementation engages other actors. The subsequent sections explain the health and economic costs of tobacco in Bangladesh, and the key findings and outcomes of this analysis. Although we have created separate themes to present our findings, these themes are not mutually exclusive.

\subsection{Administration of Tobacco Control Policy in Bangladesh}

Immediately after enacting the 2005 Anti-tobacco law, the government allocated the administrative tasks among several ministries and divisions to implement the law. In 2007, the government formulated the National Strategic Plan of Action for Tobacco Control (2007-2010), which outlined the roles of various administrative bodies, including the ministries (GoB, 2007). The Ministry of Health and Family Welfare (MoHFW) was given the lead role, and the National Tobacco Control Cell (NTCC) was established under the ministry. To assist NTCC and MoHFW to develop and implement tobacco control policies, several multi-sectoral bodies were set up. The National Task Force for Tobacco Control (NTFTC), headed by the Health Secretary ${ }^{4}$, was set up. Representatives from all relevant government bodies, CSOs, legal and media organizations and international development partners were given membership of this committee. Following this format, task force committees were also formed at the district and sub-district levels, headed by the respective chief executive officers of the administrative units. These local level committees were supposedly accountable to NTCC. Jackson-Morris et al. (2015) argue that these decentralized administrative structures for enforcing tobacco control laws was innovative and sustainable since it could engage local authorities and community-based organizations with low operational costs. S. Ahmed et al. 
(2019) acknowledge that the combination of the NTCC and the three task force committees laid a solid institutional foundation for tobacco control in Bangladesh.

The policy implementation also directly involves several other important ministries. The Ministry of Agriculture (MoA) was given the responsibility to reduce tobacco cultivation, the Cabinet Division and Ministry of Public Administration (MoPA) and Local Government Division (LGD) has the responsibility of enforcing the law through mobile courts, the Ministry of Home $(\mathrm{MoH})$ to check illegal tobacco trades, the Ministry of Finance (MoF) to manage taxation, the Ministry of Industry (MoI) to supervise the tobacco industry, and the Ministry of Information and Broadcasting (MoIB) to cease advertisement and promotional activities.

Table 1. Tobacco control policy administration in Bangladesh [Adapted/Extended from S. Ahmed et al. (2019, p. 423)]

\begin{tabular}{|c|c|c|}
\hline Ministry/Division & $\begin{array}{l}\text { Enforcing } \\
\text { Departments/Bodies }\end{array}$ & Responsibilities \\
\hline $\begin{array}{l}\text { Ministry of Health } \\
\text { and Family Welfare }\end{array}$ & $\begin{array}{l}\text { National Tobacco Control } \\
\text { Cell (NTCC) }\end{array}$ & $\begin{array}{l}\text { Develop Tobacco control policies, action plans, and } \\
\text { check compliance of the Act } \\
>\text { Coordinate with national level CSOs, NGOs, and } \\
\text { partner organizations } \\
>\text { Conduct meetings of NTFTC }\end{array}$ \\
\hline Ministry of Finance & $\begin{array}{l}\text { National Board of } \\
\text { Revenue (NBR) }\end{array}$ & $\begin{array}{l}>\text { Propose and develop tax structures for tobacco } \\
\text { products } \\
>\text { Identify and investigate revenue shortfalls } \\
>\text { Enforce tax and VAT (Value Added Tax) } \\
\text { compliance } \\
>\text { Collect health surcharge imposed on tobacco } \\
\text { products }\end{array}$ \\
\hline $\begin{array}{l}\text { Cabinet Division } \\
\text { Ministry of Public } \\
\text { Administration }\end{array}$ & $\begin{array}{l}\text { Field Administration } \\
\text { (Divisional } \\
\text { Commissioner, Deputy } \\
\text { Commissioner, Upazila } \\
\text { Nirbahi Officers) } \\
\text { Executive magistracy }\end{array}$ & $\begin{array}{l}>\text { Conduct monthly meetings } \\
>\text { Engage local CSOs and NGOs } \\
>\text { Implementation of the Act and policies } \\
>\text { Conduct mobile courts to check for non-compliance }\end{array}$ \\
\hline $\begin{array}{l}\text { Ministry of } \\
\text { Agriculture }\end{array}$ & $\begin{array}{l}\text { Department of } \\
\text { Agricultural Extension }\end{array}$ & $\begin{array}{l}>\text { Discourage farmers to cultivate tobacco } \\
>\text { Promote alternative crops }\end{array}$ \\
\hline $\begin{array}{l}\text { Ministry of } \\
\text { Information and } \\
\text { Broadcasting } \\
\end{array}$ & Relevant departments & $\begin{array}{l}\text { Monitor and enforce bans on advertisements and } \\
\text { promotion of tobacco products } \\
>\text { Disseminating information for public awareness }\end{array}$ \\
\hline Ministry of Home & $\begin{array}{l}\text { Bangladesh Police } \\
\text { Coast Guard } \\
\text { Border Guard Bangladesh }\end{array}$ & $\begin{array}{l}\text { Assist on-ground enforcements against any non- } \\
\text { compliance of the Act } \\
>\text { Check illicit trades and smuggling }\end{array}$ \\
\hline $\begin{array}{l}\text { Ministry of Local } \\
\text { Government, Rural } \\
\text { Development and } \\
\text { Cooperatives }\end{array}$ & $\begin{array}{l}\text { Local Government } \\
\text { Division }\end{array}$ & $\begin{array}{l}\text { Ensure compliance of the Act through local } \\
\text { government institutions } \\
>\text { Monitor the progress } \\
>\text { Arrange mobile courts against non-compliance }\end{array}$ \\
\hline
\end{tabular}

The above table (Table 1) summarizes the tobacco control policy administration in Bangladesh. It also indicates 
the major public-sector players in the implementation of tobacco policies in the country. Apart from these government bodies, the Ministry of Law, Justice, and Parliamentary Affairs has some direct responsibilities regarding scrutinizing the proposed legal reforms for tobacco. We need to explore the behavior of these stakeholders regarding the implementation to explore the politics of tobacco control in Bangladesh.

\subsection{Shedding Light on the Health and Economic Costs of Tobacco}

The detrimental effects of tobacco on human health are widely known and acknowledged. According to WHO's latest estimates published in 2019, globally, more than 8 million premature human deaths are caused by tobacco consumption, of which 7 million are reported to be caused by direct use, while exposure to second-hand use takes away another 1.2 million human lives (Münzel et al., 2020; WHO, 2019). Studies estimate that about 80 percent of the deaths due to tobacco consumption occur in low and middle-income, and developing countries (Drope \& Schluger, 2018; Khandker et al., 2017; WHO, 2011). Being the $12^{\text {th }}$ largest tobacco producer in the world, the burden of tobacco and its related deaths and illnesses are also widely prevalent in Bangladesh. Faruque et al. (2020) estimated that in 2018, tobacco use caused around 126,000 premature deaths, which accounting for 13.5 percent of deaths from any cause in that particular year. The study also found that nearly 1.5 million Bangladeshi adults were suffering from diseases related to tobacco consumption, while approximately 61,000 children were affected by diseases induced by the exposure to secondhand smoking.

However, several interviewees state that the real economic cost of tobacco use remains understated in policy-level discussions in Bangladesh. Following the cost-of-illness ${ }^{5}$ approach, Faruque et al. (2020) estimate that tobaccoinduced deaths and diseases cost the country's economy approximately USD 3.61 billion a year, which was equivalent to 1.4 percent of its national GDP in the fiscal year of 2017-18. To defend their slow and soft approach to control tobacco, most policymakers often use the rhetoric that tobacco cultivation generate substantive employment and income for tobacco farmers, while its manufacturing creates employment and ensures the livelihoods of thousands of farmers and their families across the country. Genilo and Sharif (2015) showed how major tobacco companies propagate the discourse of direct and indirect human resource employment through very carefully designed communication materials and corporate social responsibility activities. However, emerging evidence increasingly contest and oppose this argument. For instance, a recent survey result shows that the cumulative cost of environmental, unpaid family labor, and health effects of tobacco is in fact a losing economic concern (Hussain et al., 2020). Yet, several interviewees, including an ex-employee of a multinational tobacco company and a current employee of the National Board of Revenue (NBR), reveal that the former narrative (creates employment and ensures livelihoods) dominates the key ministerial level policymaking discussions. Persistent lobbying from the financially powerful and strong tobacco companies at the government level further nurtures their narratives among relevant policymakers.

\subsection{Translating Ideas into Institutions}

Historically, farmers across the country were heavily encouraged to cultivate tobacco plants since it was considered a major agricultural cash crop until the idea of tobacco control was brought in to Bangladesh (Rahman \& Parvin, 2017). Before passing the anti-tobacco laws in 2005, the government provided all kinds of support to tobacco businesses to enable them to grow. Standing on this state support, tobacco companies encouraged rural farmers to spread tobacco cultivation through financial incentives and promotional campaigns, including contract farming ${ }^{6}$ (Akhter, 2017; Begum et al., 2012). PRI (2016) found that farmers continue to cultivate tobacco since it yields the highest return amongst all crops. As a result, tobacco cultivation and consumption remains a deeply rooted culture in Bangladesh (Hoque, 2020). Despite having restrictive laws in place, tobacco still has deep penetration in cultural practices. Although public smoking is not a widely accepted and normalized social behavior in the country, big socio-cultural and political events are often observed and celebrated with some form of tobacco use in place. For instance, in rural areas, smokeless tobacco is still regularly offered in marriage ceremonies, while election campaigns offer smoking packs as part of their promotional activities.

However, tobacco control as a political idea was not home-grown but rather imported. It was imported in the sense that tobacco control policies were introduced based on reports and evidence produced outside the country. The CSOs took up this politically "minor issue" to the state and later successfully engaged like-minded people and organizations to sustain the movement against tobacco (Efroymson \& Ahmed, 2003). Several research and advocacy campaigns logically illustrated the wider harmful socio-economic implications of tobacco use the early 2000s. Eventually, Bangladesh became the first country to sign FCTC in 2003. While speaking about this extraordinary event, an interviewee said:

Bangladesh signed the treaty since the former government thought it to be the right thing to do, but there was no institutional readiness when the policy was adopted. The subsequent institutional developments 
were mostly driven by the treaty requirements, not by any popular political demand. The subsequent governments seemed to be hesitant to build a strong institutional mechanism to control or cease tobacco. WHO and CSOs are still advocating to the government to adopt required reforms and action plans but the response from the government is slow and often unclear.

This statement reflects a few crucial aspects of the issue. First, since the demand for tobacco control was not a bottom-to-up political agenda, the government and elected policymakers never felt truly accountable for it to the citizens, although reports and interviewees' testimonies indicate that tobacco control as an implementing policy action has gained substantive moral support from the people. Smoking in public locations and workplaces has notably reduced over the last two decades. Tobacco farmers and manufacturers are aware of their moral dilemmas (Rahman \& Parvin, 2017). Yet, the idea of tobacco control has not been transformed into a political agenda. Second, the actions of the state so far reflect a serious lack of commitment (elaborated in the following section) in implementing tobacco control policies not only to embrace needed reforms, but also to strictly enforce existing laws and regulations. This indicates that the issue of tobacco control is a strategic accommodation. Barraclough and Morrow (2010) recognized a similar phenomenon in the case of Thailand's tobacco control programme. They argued that a strategic accommodation signifies a paradoxical situation where the viability of the tobacco industry is assured, while at the same time, the state claims to put all measures in place to dissuade its citizens from consumption. Therefore, there is a dichotomy here. Third, from a policy implementation perspective, the statement reflects that tobacco control is currently not a policy priority. Several research works indicate that the lobbying, influence, and interference of the tobacco companies are the main causes of such contradictory behavior by the government (Banu, 2017; Faruque et al., 2020; Rahman \& Parvin, 2017). In the 2019 Bangladesh Tobacco Industry Interference Index, the country scored 77 out of 100 (the lower the better) meaning that it remains vulnerable to the tobacco industry's under-handed tactics and interference in policy adoption and reforms (PROGGA, 2019).

It is evident that the solid foundation of institutions has not been built upon in this case. After the 2013 amendment of the Smoking and Tobacco Products Usage (Control) Act 2005, several institutional reforms took place, including notification of the Rules for the Act in 2015, making graphic health warning on tobacco packs mandatory, putting a $1 \%$ health surcharge on tobacco products in 2017 , and creating a custom of increasing tax on tobacco annually. Although these important reforms reflect consistent institutional development, they are notably minor strides. Moreover, several interviewees recognize the dearth of efforts to influence informal institutions regarding tobacco consumption. The health warning "Tobacco kills" remains widely circulated, but other than that there is no largescale government-led awareness programme or intervention aiming to challenge the existing harmful social norms of widespread tobacco use in the country. NGOs and advocacy organizations continue their efforts to bring cultural changes at the national and grassroot levels, but these efforts need to be coupled with institutional support from the government to be effective (Driezen et al., 2016).

\subsection{Demystifying Government's Commitment}

Political commitment is a critical factor in explaining the policy ambiguity, lack of implementation, and operational and institutional ineffectiveness within a tobacco end-game strategy framework (Boëthius et al., 2018; Hoe et al., 2019). In low and middle-income countries, political commitment plays an important role in mobilizing public support for anti-tobacco implementation (Bump \& Reich, 2013; Craig et al., 2019; Tumwine, 2011). Bangladesh has built a solid legislative and institutional foundation and showed a solid commitment towards tobacco control. However, as Pettit and Acosta (2014) emphasize, PEA is about deep-diving below the line to explore the motivations of key stakeholders. Insights gained from the interviewees help us to delve deeper into this case. An activist who also represents a national-level advocacy organization stated:

We must admit that the government has strong commitment toward tobacco control since the Head of the Government herself declared that her government aims to be tobacco-free by 2040 . However, in several situations, the behavior of key ministries has remained ambiguous, and interest groups continue to influence government decisions from unknown places. Still, we need to acknowledge that the political will is there.

In 2016, the incumbent Prime Minister (PM), while attending the South Asian Speakers' Summit on Achieving Sustainable Development Goals, said, "although we have made notable progress in tobacco control, we have to do more to fully comply with the FCTC and all sorts of steps will be taken to make Bangladesh tobacco-free by 2040 " (Bdnews24, 2016). Since then, both government and non-government organizations (NGOs) have referred to this remarkable statement to report and highlight the political will of the government. The abovementioned activist also points this out. However, evidence suggests that this apex-level political will has not trickled down to the national level, where the commitment is rather skewed and unclear. The following sub-sections elaborate on this 
point.

\subsubsection{Lack of Commitment in Comprehensive Actions}

Currently, there is no action plan activated that could integrate all headways together. The initial action plan which was passed in 2007 was no longer valid after 2010. After 2010, NTCC failed to adopt any more national policy plans that could tighten the control over tobacco. Referring to the PM's declaration, NTCC formulated two important draft policies with a view to realize the country's vision of being a tobacco-free country by 2040 . One of the two is a comprehensive roadmap which outlined the yearly plan of actions from 2020 to 2040. An employee of NTCC shared his views about the roadmap:

Unfortunately, we have not been able to finalize the document (roadmap) for various reasons including the on-going coronavirus pandemic. It was formulated in early 2019 and was designed to be operational in 2020 . We look forward to having it passed by the government. It will be useful for all of us (who are working towards tobacco control) as a reference document. Interestingly, a few ministries which sent strong written opinions in favor of strong measures in the proposed roadmap have recently informed us that they have altered their position.

This testimony clearly reveals the government's lack of attention, intention, and commitment to endorse the allimportant roadmap which can bring all government apparatus together towards achieving the vision. The second policy was the National Tobacco Cultivation Control Policy, which was formulated as a draft in 2017 with a view to gradually reduce tobacco cultivation. This document could not be finalized either and unexpectedly the draft document has been removed from the NTCC website.

\subsubsection{Intra-Government Conflict of Interests}

Bump and Reich (2013) note that intra-government conflict of incentives among the ministries also reflect the lack of commitment. 'Working in silos' has been a commonly identified challenge for effective policy implementation in Bangladesh (Haque et al., 2019). Tobacco control is no exception, and it is not a mere lack of coordination or communication among the government bodies, but rather an implicit conflict of interests. Although on paper, all bodies agree that Bangladesh should get rid of tobacco soon, their actions are often divergent. For instance, the Ministry of Finance (MoF) asks the National Board of Revenue (NBR) to generate revenues to reduce the deficit in the annual budget, and officers of NBR work towards achieving that target, and although tobacco taxation in Bangladesh is quite complicated, it is an important source of revenue for the government (S. Ahmed et al., 2019). N. Ahmed et al. (2019) reported that tobacco tax revenues contributed BDT 22,866.91 crore (about 2.74 billion USD) in FY 2017-18, accounting about 11 percent of total tax revenues, and more than 1 percent of GDP. From FY 2013/14 to FY 2017/18, the annual growth of tobacco revenues (excluding profit tax) was recorded at 16 percent. Considering the value of the generated revenues, government dependency on tobacco is therefore still considerably high as it plays a pivotal role in helping the government to reduce its annual budget deficits, as well as creating employment. As a result, NBR has substantive political leverage in the tobacco control policy domain.

NTCC, in contrast, struggles to make its voice heard at the top levels of the government since it has to go through MoHFW. The NTCC employee adds, "We fail to put through our messages to the Cabinet or to the Parliament since our original message and content gets filtered and altered by the officials of the health ministry; and strong voices often get soft". Moreover, the activism of MoHFW in this regard is largely reliant on the advocacy campaigns run by the CSOs and partner organizations. Referring to the deleterious health consequences and economic costs of tobacco, NTCC got the National Health Development Surcharge Management Policy 2017 adopted by the Government. The policy enabled NTCC to utilize the $1 \%$ health development surcharge that was applicable from all tobacco products towards sustainable tobacco control in Bangladesh (NTCC, 2017). However, although the surcharge has been collected by NBR in the last three years, NTCC did not get receive any of it. NTCC and MOFHW both have relatively low bargaining power in the domain. These intra-government conflicts eventually hurt the implementation of tobacco control policies.

\subsubsection{State-Business Nexus}

Often, elected leaders and policymakers are found to have ownership or interests in a political economy (Hoque, 2018a). The nexus between government and tobacco businesses is an open secret. In Bangladesh, for example, the very same government which sets a target to make the nation free of tobacco, has part-ownership of the country's biggest tobacco conglomerate - the British American Tobacco Bangladesh (BATB). Several sources, including the website of the company, state that various government agencies altogether own about 13 percent of its shares, and occupy 6 out of 10 posts in the company's board of directors (Hasnain, 2019). Several sitting Members of 
Parliament (MPs) are also involved in tobacco businesses (N. Ahmed et al., 2019). When asked about this government investment and potential conflict of interest, a top government official replied:

Tobacco companies, including BATB, are operating within the legal framework of the country, and pay taxes accordingly. The government is also working to make people aware about the harmful effects of tobacco. We hope people will stop using tobacco soon, and the businesses will cease too.

This controversial nexus has a few critical implications. First, it makes the government lose moral ground when it comes to being strict about the issue of tobacco use, and provides the businesses the ethical leverage to operate widely. Second, it violates the Article 5.3 of FCTC which obliges parties to the treaty by promising to "protect their public health policies related to tobacco control from commercial and other vested interests of the tobacco industry". The country continued to violate the treaty when it welcomed a foreign investment from the Japan Tobacco Group in acquiring a local tobacco business of Akij Group in 2018 (Reuters, 2018). This clearly undermines the country's strategy towards tobacco control, and influences the government's taxation policies as well.

Evidence suggests that tax and price policies are the most effective ways to reduce the demand of tobacco products (Marquez, 2017; van Walbeek \& Filby, 2019). WHO's policy package MPOWER ${ }^{7}$ also demands for raising taxes. Several studies argue that NBR must drop its existing multi-tiered tax system and adopt legal reforms to introduce a uniform specific tax system (N. Ahmed et al., 2019; Nargis et al., 2020). However, there is no sign of such adoption at present. An employee of NBR shares:

NBR will have to adopt specific tax system someday, but right now it is not an agenda. In the top-level discussions, this issue remains ignored. NBR focuses on raising revenue, and the tobacco industry is a big source. Every year, NBR receives tax proposals from the companies, and it imposes accordingly. Tobacco conglomerates are professionally aggressive, and they make all kinds of efforts to influence various levels of NBR employees to secure their support. Many of my colleagues have received illegitimate offers.

This statement indicates two major issues. First, the current government emphasizes on the growth of Gross Domestic Product (GDP) by increasing the volume of production and employment. The revenue generated by NBR works as an engine to push this economic growth upwards, and the tobacco industry plays a salient part in this regard. Hence, over-taxing may hurt common interests. Second, the meddling of tobacco companies in both policy reforms and implementation is worrisome. A few years back, NBR used to have a separate cell to conduct research and propose required tax reforms, but the cell is now inactive, an interviewee informs. This clearly indicates the lack of commitment from NBR towards tobacco control.

\subsection{Funding Remains an Issue}

Tobacco control is largely an externally funded agenda in Bangladesh. NTCC runs as a Bloomberg Initiative to Reduce Tobacco Use Grants Program (funded by Bloomberg Philanthropies ${ }^{8}$ ), and the staff receive their salary from the external funding. Although as an organization it works under MoHFW, it does not receive any permanent revenue funding from the government. In FY 2020-21, NTCC received about BDT 20 crore, which is approximately 0.07 percent of the budget allocated for health services, health education, and family welfare. This fund was mostly spent on awareness-building campaigns through state-owned media platforms. NTCC is run by a Program Director who is appointed by the MoHFW. The organization has only 5 employees and has not been formally included in the organogram of MoFHW. It is undeniable that NTCC as an organization remains understaffed and under-prioritized. It clearly lacks both human and financial resources and does not have the capacity to effectively deliver on its responsibilities. The government also does not allocate any budget for CSOs and NGOs to run their activities. These organizations are also largely dependent on external funds.

In contrast, due to substantive annual turnovers, tobacco companies can afford to spend a lot of money for underground promotional activities and to sustain their nexus with government bodies. Even during the pandemic, in 2020 BATB made a profit of BDT 1,088 crore (USD 128 million approximately), up 36.9 percent year-on-year (Mahmud, 2021). Apart from various CSR-led promotional programs, tobacco companies fund research work to produce evidence that can nullify the findings and claims of advocacy organizations (e.g., PRI (2016)). An exemployee of a tobacco company shares:

The companies operate for profit. They recruit the brightest graduates from the top public universities in Bangladesh. They provide them with excellent facilities and train them to bring back the results they want even in the most adverse environments. 
This testimony resembles that of several other interviewees. The big companies carefully design their CSR-led and underground strategies to influence the key individuals inside the administrative system.

\subsection{Sedentary Committees, Active Individuals}

The committees in charge of implementing the law at the national and regional levels remain predominantly inactive. Although the National Task Force for Tobacco Control (NTFTC) was supposed to meet at regular intervals, it has not convened in the last four years. The district and sub-district level committees are supposed to meet once in every three months and report to the NTCC. We interviewed two members of the district committee. A few findings are critical and need to be mentioned. First, individuals are important. In those districts and subdistricts where the chairpersons of the committees are non-smokers, tobacco control activities are found to be active and ongoing. Grassroots-level NGOs are reported to be actively participating in these meetings. Second, in places (districts/sub-districts) where tobacco is not cultivated, the committee tends to avoid holding meetings. Third, although meetings are irregular, mobile courts have been operational to enforce the law at the district level. The Executive Magistrates who are non-smokers or strongly support tobacco control agenda tend to actively conduct mobile courts.

According to a NTCC report, the organizations regularly receive the resolutions from some committees. Although the activities have slowed down due to the ongoing pandemic, some district-level committees remained vigilant in terms of tobacco control. The local government institutions received the government notification about their responsibilities just a few months ago, and therefore they are yet to be operational. However, at all levels of policy implementation, individuals' political behaviors continue to play critical roles. For instance, every year during the pre-budget period a handful of MPs appeals to NBR not to increase tobacco tax (being influenced by tobacco companies), while some MPs persistently advocate for tobacco control (N. Ahmed et al., 2019; Amin, 2020). The movement against tobacco is driven by like-minded activists and NGOs, and the implementation of tobacco control policies is still propelled by the will of one individual - the head of the government.

\section{Conclusion}

The purpose of this study was to explore the political and economic dynamics currently active in either enabling or impeding policy reforms and implementation of policies regarding tobacco control in Bangladesh. After engaging with relevant literature and policy documents, we attempted to provide a PEA that could explain how those political and economic dynamics interact to sustain the state of sluggishness and complexity. Despite some limitations, the findings and analysis of this study answers several 'why and how' questions and makes novel contributions to the field. Furthermore, it also provides a critical understanding of the implications for activists, policy makers and implementers. PEA does not offer a direct solution to a problem but offers below-the-surface insights that illustrate the key impediments to be addressed. This research identified some key issues which can be further investigated.

This study has some notable limitations. Since this is a national level sector-based PEA, we heavily focused on the government bodies and the dynamics related to the implementation. Further studies can investigate the role of other actors, including those in businesses and judiciary. We also acknowledge that country and local-level analysis, combined in addition to this study, can bring about a more comprehensive understanding of the issue. However, based on the above accounts of findings and analysis, we can highlight three key points here. First, tobacco control policy administration in Bangladesh is well designed but not executed to its full potential. Second, since the idea of tobacco control is not fully home grown, it has not transformed into an explicit political agenda in Bangladesh. Third, the political will of becoming a tobacco-free nation is strongly present in most narratives, but intragovernment conflicts of interest, skewed commitment of government bodies, the strong state-business nexus, organizational incapacity of NTCC, and the dubious role of key individuals and committees, fail to translate this will into active implementation. Tobacco remains out of control.

Based on the research work and our findings, we recommend that the government agencies must convene their efforts towards one common goal, which is to create a tobacco-free Bangladesh. The government ought to meaningfully engage private and civil society organizations towards achieving this goal. It must start with empowering NTCC with adequate power, authority, and resources to function independently and effectively. Formulating and following a well-articulated and farsighted roadmap could also be the key. Finally, the implementation requires genuine government commitment, active and willful participation of all stakeholders, and wider public support.

\section{Acknowledgments}

The authors express their sincere gratitude to the interviewees who actively participated in this research work. All 
participant interviewees were adult humans. The authors are also grateful to the anonymous reviewers for their insightful and constructive comments and observations.

\section{References}

Ahammed, T., Ahmed, N. U., \& Uddin, M. J. (2021). Changes in prevalence, and factors associated with tobacco use among Bangladeshi school students: Evidence from two nationally representative surveys. BMC Public Health, 2l(1), 579. https://doi.org/10.1186/s12889-021-10623-0

Ahmed, N. (2021). What should be the cigarette tax structure for FY2022? The Daily Star. Retrieved from https://www.thedailystar.net/business/economy/news/what-should-be-the-cigarette-tax-structure-fy20222089069

Ahmed, N., Hossain, J., Huque, R., Hassan, Md. T., \& Mozumder, T. A. (2019). The Economics and Tobacco Taxation in Bangladesh. Brac Institute of Governance and Development. Retrieved from https://tobacconomics.org/uploads/misc/2019/10/tobacco_taxation_r14102019-1.pdf

Ahmed, S., Sattar, Z., \& Alam, K. (2019). Bangladesh: Illicit Tobacco Trade. In Confronting Illicit Tobacco Trade: A global review of country references (1st ed., pp. 407-437). Global Tobacco Control Program, World Bank Group). Retrieved from https://www.worldbank.org/en/topic/tobacco/publication/confronting-illicittobacco-trade-a-global-review-of-country-experiences

Akhter, F. (2017). Prioritizing food production over tobacco farming in Bangladesh [Advocay]. Development. Retrieved from http://ubinig.org/index.php/home/showAerticle/94/english/-Farida-Akhter/Prioritizing-foodproduction-over-tobacco-farming-in-Bangladesh

Amin, M. A. (2020). MPs seek additional Tk11,000cr by increasing taxes on tobacco products. Dhaka Tribune. Retrieved from https://www.dhakatribune.com/business/2020/06/07/mps-seek-additional-tk11-000cr-byincreasing-taxes-on-tobacco-products

Banu, N. (2017). Tobacco Industry Interference: Bangladesh perspective. Social Change, 7(1), 23-45.

Barai, M. K. (2020). Introduction: Construction of a Development Model for Bangladesh. In M. K. Barai (Ed.), Bangladesh's Economic and Social Progress (pp. 3-62). Springer Singapore. https://doi.org/10.1007/978981-15-1683-2_1

Barkat, A., Chowdhury, A. U., Nargis, N., Rahman, M., Khan, Md. S., Kumar, A., Bashir, S., \& Chaloupka, F. J. (2012). The Economics of Tobacco and Tobacco Taxation in Bangladesh. International Union Against Tuberculosis and Lung Disease.

Barkat, A., Majid, M., Mahiyuddin, G., Rahman, M., Munir, A., Kumar, A., \& Khan, M. S. (2008). Contract Farming in Bangladesh: Political Economy of Tobacco Cultivation and Processing [Study Report]. Retrieved from Human Development Research Centre. https://www.hdrc-bd.com/wp-content/uploads/2019/01/02.Contract-farming-in-Bangladesh_-Political-economy-of-tobacco-cultivation-and-processing.pdf

Barraclough, S., \& Morrow, M. (2010). The political economy of tobacco and poverty alleviation in Southeast Asia: Contradictions in the role of the state. Global Health Promotion, 17(1_suppl), 40-50. https://doi.org/10.1177/1757975909358243

BBS. (2018). Comparison Fact Sheet: Bangladesh 2009 and 2017 (p. 2) [Survey Report]. Global Adult Tobacco Survey. Retrieved from http://bbs.portal.gov.bd/sites/default/files/files/bbs.portal.gov.bd/page/57def76a_aa3c_46e3_9f80_53732eb 94a83/GATS_BAN_2017_Comparison_Fact\%20Sheet.pdf

BBS, \& NTCC. (2019). Global Adult Tobacco Survey: Bangladesh Report 2017. Bangladesh Bureau of Statistics and National Tobacco Control Cell.

Bdnews24. (2016, January 31). PM Hasina hopes to make Bangladesh tobacco free within 2040. Bdnews24.Com. Retrieved from https://bdnews24.com/bangladesh/2016/01/31/pm-hasina-hopes-to-make-bangladeshtobacco-free-within-2040

Beaglehole, R., Bonita, R., Yach, D., Mackay, J., \& Reddy, K. S. (2015). A tobacco-free world: A call to action to phase out the sale of tobacco products by 2040. The Lancet, 385(9972), 1011-1018. https://doi.org/10.1016/S0140-6736(15)60133-7

Begum, I. A., Alam, M. J., Buysse, J., Frija, A., \& Van Huylenbroeck, G. (2012). Contract farmer and poultry farm efficiency in Bangladesh: A data envelopment analysis. Applied Economics, 44(28), 3737-3747. https://doi.org/10.1080/00036846.2011.581216 
Boëthius, G., Sjöberg, L., \& Thörnqvist, E. (2018). Mobilizing public opinion for a political commitment for a Tobacco Endgame strategy-Obstacles and possibilities. Tobacco Induced Diseases, 16(1). https://doi.org/10.18332/tid/84297

Booth, D., \& Cammack, D. (2009). Political Economy Analysis "How to Note" [Practice Paper]. DFID and Overseas Development Institute. Retrieved from https://odi.org/en/publications/political-economy-analysishow-to-note/

Bump, J. B., \& Reich, M. R. (2013). Political economy analysis for tobacco control in low- and middle-income countries. Health Policy and Planning, 28(2), 123-133. https://doi.org/10.1093/heapol/czs049

Bump, J. B., Reich, M. R., Adeyi, O., \& Khetrapal, S. (2009). Owards a Political Economy of Tobacco Control in Low- and Middle-Income Countries (Health, Nutrition and Population (HNP)) [Discussion Paper]. World Bank. Retrieved from https://openknowledge.worldbank.org/handle/10986/13799

Cairney, P., Studlar, D. T., \& Mamudu, H. (2012). Global tobacco control: Power, policy, governance and transfer. Palgrave Macmillan.

Chantornvong, S., \& McCargo, D. (2001). Political economy of tobacco control in Thailand. Tobacco Control, 10(1), 48-54. https://doi.org/10.1136/tc.10.1.48

Choudhury, S. R. (2017). Making Bangladesh Tobacco Free by 2040: Where We Stand Now and Future Projections. Social Change, 7(1), 1-4.

Craig, L., Fong, G. T., Chung-Hall, J., \& Puska, P. (2019). Impact of the WHO FCTC on tobacco control: Perspectives from stakeholders in 12 countries. Tobacco Control, 28(Suppl 2), s129-s135. https://doi.org/10.1136/tobaccocontrol-2019-054940

Driezen, P., Abdullah, A., Nargis, N., Hussain, A., Fong, G., Thompson, M., Quah, A., \& Xu, S. (2016). Awareness of Tobacco-Related Health Harms among Vulnerable Populations in Bangladesh: Findings from the International Tobacco Control (ITC) Bangladesh Survey. International Journal of Environmental Research and Public Health, 13(9), 848. https://doi.org/10.3390/ijerph13090848

Drope, J., \& Schluger, N. W. (2018). Tobacco Atlas (Sixth). McGraw-Hill Education. Retrieved from https://tobaccoatlas.org/wp-content/uploads/2018/03/TobaccoAtlas_6thEdition_LoRes_Rev0318.pdf

Efroymson, D. (2000). Bangladesh: Voyage of disdain sunk without trace. Tobacco Control, 9(2), 129b-1129. https://doi.org/10.1136/tc.9.2.129b

Efroymson, D., \& Ahmed, S. (2003). Building Momentum for Tobacco Control: The Case of Bangladesh. In Tobacco Control Policy Strategies, Successes, and Setbacks (pp. 13-37). The International Bank for Reconstruction and Development.

FAO. (2017). Political Economy Analysis (Policy Guidance Note, p. 30). Food and Agriculture Organization of the United Nations. Retrieved from http://www.fao.org/3/i7212en/I7212EN.pdf

Faruque, G. M., Ahmned, M., Iftekharul Huq, Perven, R., Wadood, S. N., Chowdhury Sohel Reza, Akm Ghulam Hussain, Haifley, G., Drope, J. M., \& Nargis, N. (2020). The Economic Cost of Tobacco Use in Bangladesh: A Health Cost Approach. https://doi.org/10.13140/RG.2.2.33392.28169/1

Genilo, J. W. R., \& Sharif, M. R. (2015). Tobacco industry governance and responsibility discourses in Bangladesh. South East Asia Journal of Public Health, 5(2), 10. https://doi.org/2313-531X

GoB. (2007). National Strategic Plan of Action for Tobacco Control (2007-2010). Ministry of Health and Family Welfare, Government of Bangladesh (GoB). Retrieved from https://www.ghdonline.org/uploads/BGD_Tobacco_Plan_of_Action.pdf

Haider, H., \& Sumedh, R. (2010). Political and social analysis for development policy and practice: An overview of five approaches (p. 37) [Monograph]. University of Birmingham. Retrieved from http://epapers.bham.ac.uk/1516/

Haque, M., Pervin, M., Sultana, S., \& Huq, S. (2019). Towards Establishing a National Mechanism to Address Losses and Damages: A Case Study from Bangladesh. In R. Mechler, L. M. Bouwer, T. Schinko, S. Surminski, \& J. Linnerooth-Bayer (Eds.), Loss and Damage from Climate Change (pp. 451-473). Springer International Publishing. https://doi.org/10.1007/978-3-319-72026-5_19

Hasan, K. M. (2020). Farmer's Response to Tobacco Processing Company in Tobacco Cultivation in Bangladesh. Annals of Public Health \& Epidemiology, 1(1), 1-11. https://doi.org/APHE.MS.ID.000503. 
Hasnain, M. (2019). Divestment holds the key to tobacco-free Bangladesh by 2040. Bdnews24.Com. Retrieved from https://opinion.bdnews24.com/2019/04/06/divestment-holds-the-key-to-tobacco-free-bangladesh-by2040/

Hoe, C., Kennedy, R. D., Spires, M., Tamplin, S., \& Cohen, J. E. (2019). Improving the implementation of tobacco control policies in low-and middle-income countries: A proposed framework. BMJ Global Health, 4(6), e002078. https://doi.org/10.1136/bmjgh-2019-002078

Hoque, M. M. (2016). Tobacco Control Politics in Bangladesh [MA Dissertation, University of Sussex]. Retrieved from https://philpapers.org/rec/HOQTCP

Hoque, M. M. (2018a). Information Institutions and the Political Accountability in Bangladesh. International Journal of Scientific \& Engineering Research, 9(2), 1586-1596.

Hoque, M. M. (2018b). The Image Crisis of India as a Development Partner in South Asia: A Regional Development Perspective (SSRN Scholarly Paper ID 3735401). Social Science Research Network. Retrieved from https://papers.ssrn.com/abstract=3735401

Hoque, M. M. (2020). World No Tobacco Day: Can Bangladesh be tobacco-free by 2040? The Daily Star. Retrieved from https://www.thedailystar.net/law-our-rights/news/world-no-tobacco-day-can-bangladesh-betobacco-free-2040-1906411

Hoque, M. M. (2021). Forced Labour and access to Education of Rohingya Refugee Children in Bangladesh: Beyond a Humanitarian Crisis. Journal of Modern Slavery, 6(3), 20-35. https://doi.org/10.22150/jms/PPJY4309

Hoque, M. M., \& Tama, R. A. Z. (2020). China's Belt and Road Initiative: Global Politics and Implications. European Scientific Journal ESJ, 16(31). https://doi.org/10.19044/esj.2020.v16n31p279

Hossain, Md. M. (2013). A Socioeconomic Analysis on Tobacco Cultivation in Kushtia District of Bangladesh. Social Sciences, 2(3), 128. https://doi.org/10.11648/j.ss.20130203.14

Hudson, D., \& Leftwich, A. (2014). From Political Economy to Political Analysis (Developmental Leadership Program, p. 122) [Research Report]. University of Birmingham. Retrieved from https://gsdrc.org/documentlibrary/from-political-economy-to-political-analysis/

Hussain, A. G., Rouf, A. S. S., Shimul, S. N., Nargis, N., Kessaram, T. M., Huq, S. M., Kaur, J., Shiekh, M. K. A., \& Drope, J. (2020). The Economic Cost of Tobacco Farming in Bangladesh. International Journal of Environmental Research and Public Health, 17(24), 9447. https://doi.org/10.3390/ijerph17249447

Islam, Md. S. (2021). Ready-made garments exports earning and its contribution to economic growth in Bangladesh. GeoJournal, 86(3), 1301-1309. https://doi.org/10.1007/s10708-019-10131-0

Jackson-Morris, A., Chowdhury, I., Warner, V., \& Bleymann, K. (2015). Multi-Stakeholder Taskforces in Bangladesh-A Distinctive Approach to Build Sustainable Tobacco Control Implementation. International Journal of Environmental Research and Public Health, 12(1), 474-487. https://doi.org/10.3390/ijerph120100474

Jarman, H. (2015). The politics of trade and tobacco control. Palgrave Macmillan.

Khandker, N. N., Biswas, T., Khan, A. N. S., Hasib, E., \& Rawal, L. B. (2017). Socio-demographic characteristics and tobacco use among the adults in urban slums of Dhaka, Bangladesh. Tobacco Induced Diseases, 15(1), 26. https://doi.org/10.1186/s12971-017-0131-1

Lokot, M. (2021). Whose Voices? Whose Knowledge? A Feminist Analysis of the Value of Key Informant Interviews. International Journal of Qualitative Methods, 20, 160940692094877. https://doi.org/10.1177/1609406920948775

Mahmud, M., Otsuka, K., Sawada, Y., \& Yamada, E. (2018). Development Transformation in Bangladesh: An Overview. In Y. Sawada, M. Mahmud, \& N. Kitano (Eds.), Economic and Social Development of Bangladesh (pp. 3-26). Springer International Publishing. https://doi.org/10.1007/978-3-319-63838-6_1

Mahmud, N. (2021). BATBC posts a record year of profit amid pandemic. Dhaka Tribune. Retrieved from https://www.dhakatribune.com/business/2021/02/11/batbc-posts-a-record-year-of-profit-amid-pandemic

Marquez, P. V. (2017). Taxation: Most effective but still the least-used tobacco control measure. World Bank Blogs. Retrieved from https://blogs.worldbank.org/health/taxation-most-effective-still-least-used-tobaccocontrol-measure 
Marquez, P. V., Krasovsky, K., \& Andreeva, T. (2019). Bangladesh: Overview of Tobacco Use, Tobacco Control Legislation, and Taxation. The World Bank. Retrieved from https://documents.worldbank.org/en/publication/documents-

reports/documentdetail/230701560806135545/bangladesh-overview-of-tobacco-use-tobacco-controllegislation-and-taxation

Mondol, M., Hosain, A., Sultana, S., Marzia, S., Islam, M., Mahmud, H., \& Biswash, P. (2021). Impact of common tobacco products on human health and environmental pollution in Bangladesh. Progressive Agriculture, 31(3), 130-143. https://doi.org/10.3329/pa.v31i3.52115

Münzel, T., Hahad, O., Kuntic, M., Keaney, J. F., Deanfield, J. E., \& Daiber, A. (2020). Effects of tobacco cigarettes, e-cigarettes, and waterpipe smoking on endothelial function and clinical outcomes. European Heart Journal, 41(41), 4057-4070. https://doi.org/10.1093/eurheartj/ehaa460

Nargis, N., Hussain, A. G., Goodchild, M., Quah, A. C., \& Fong, G. T. (2019). A decade of cigarette taxation in Bangladesh: Lessons learnt for tobacco control. Bulletin of the World Health Organization, 97(3), 221-229. https://doi.org/10.2471/BLT.18.216135

Nargis, N., Hussain, A. K. M. G., Goodchild, M., Quah, A. C. K., \& Fong, G. T. (2020). Tobacco industry pricing undermines tobacco tax policy: A tale from Bangladesh. Preventive Medicine, 132, 105991. https://doi.org/10.1016/j.ypmed.2020.105991

NTCC. (2013). Smoking and Tobacco products usage (control) act 2005 (Amendment 2013). National Tobacco Control Cell, Government of Bangladesh. https://ntcc.gov.bd/

NTCC. (2017). National Health Development Surcharge Management Policy 2017. Health Services Division, Government of Bangladesh. Retrieved from https://ntcc.gov.bd/activities/details/health-developmentsurcharge-management-policy-2017

Pettit, J., \& Acosta, A. M. (2014). Power Above and Below the Waterline: Bridging Political Economy and Power Analysis. IDS Bulletin, 45(5), 9-22. https://doi.org/10.1111/1759-5436.12100

PRI. (2016). Tobacco Cultivation: An Assessment of Socio-Economic and Environmental Impacts (p. 25) [Research Report]. Policy Research Institute (PRI). Retrieved from https://swedwatch.org/wpcontent/uploads/2016/12/appendix_j_pri_socio-economic-environmental_impact_study.pdf

PROGGA. (2019). 2019 Bangladesh Tobacco Industry Interference Index: Report on Implementation of FCTC Article 5.3 (p. 29) [Index Report]. PROGGA-Knowledge for Progress. Retrieved from http://www.tobaccoindustrywatchbd.org/contents/uploaded/TII\%20Index\%20Report\%20Bangladesh\%2020 19.pdf

Rahman, A., Molla, M. H., Shahjahan, M., \& Sabur, A. (2017). Children and Tobacco in Existing Laws, Rules and Policies in Bangladesh: A Practical Scenario. Social Change, 13.

Rahman, H., \& Parvin, J. (2017). Ethics and Economics of Tobacco Farming: A Case Study of Rural Bangladesh. IOSR Journal of Humanities and Social Science, 22(02), 56-65. https://doi.org/10.9790/0837-2202045665

Rasheed, A. A., \& Sinha, S. (2012). Bidi and Bangladesh: Myths and Reality (p. 13). Campaign for Tobacco-free Kids. Retrieved from http://www.tobaccoindustrywatchbd.org/contents/uploaded/Bidi.pdf

Reuters. (2018). Japan Tobacco buying Bangladesh Akij’s tobacco business for $\$ 1.5$ billion. Retrieved from https://www.reuters.com/article/us-akij-m-a-japan-tobacco-idUSKBN1KR0O1

Rice, D. P., Hodgson, T. A., Sinsheimer, P., Browner, W., \& Kopstein, A. N. (1986). The Economic Costs of the Health Effects of Smoking, 1984. The Milbank Quarterly, 64(4), 489. https://doi.org/10.2307/3349924

Rosser, A. (2015). Contesting Tobacco-Control Policy in Indonesia. Critical Asian Studies, 47(1), 69-93. https://doi.org/10.1080/14672715.2015.997083

Salma, U., Hasan, Md. M., \& Sultana, M. I. (2020). A Regression Model-Based Approach to Identifying Determining Factors for GDP Growth in Bangladesh. 2020 International Conference on Emerging Trends in Information Technology and Engineering (Ic-ETITE), 1-6. https://doi.org/10.1109/ic-ETITE47903.2020.392

Sarker, S. A., Wang, S., Adnan, K. M. M., Anser, M. K., Ayoub, Z., Ho, T. H., Tama, R. A. Z., Trunina, A., \& Hoque, M. M. (2020). Economic Viability and Socio-Environmental Impacts of Solar Home Systems for OffGrid Rural Electrification in Bangladesh. Energies, 13(3), 679. https://doi.org/10.3390/en13030679 
Shah, S., Kanaan, M., Huque, R., Sheikh, A., Dogar, O., Thomson, H., Parrott, S., \& Siddiqi, K. (2019). Secondhand Smoke Exposure in Primary School Children: A Survey in Dhaka, Bangladesh. Nicotine \& Tobacco Research, 21(4), 416-423. https://doi.org/10.1093/ntr/ntx248

Shikha, S., \& Sultana, P. (2019). Multivariate Correspondence Analysis in Patterning Tobacco Use in Bangladesh. 691-695. Retrieved from http://www.ru.ac.bd/stat/wp-content/uploads/sites/25/2020/03/56-Suraiya-Shikhaand-Papia-Sultana_FF.pdf

Sparkes, S. P., Bump, J. B., Özçelik, E. A., Kutzin, J., \& Reich, M. R. (2019). Political Economy Analysis for Health Financing Reform. Health Systems \& Reform, 5(3), 183-194. https://doi.org/10.1080/23288604.2019.1633874

Talukder, A., Haq, I., Ali, M., \& Drope, J. (2020). Factors Associated with Cultivation of Tobacco in Bangladesh: A Multilevel Modelling Approach. International Journal of Environmental Research and Public Health, 17(12), 4277. https://doi.org/10.3390/ijerph17124277

Tama, R. A. Z., Ying, L., Happy, F. A., \& Hoque, M. M. (2018). An Empirical Study on Socio-economic Status of Women Labor in Rice Husking Mill of Bangladesh. South Asian Journal of Social Studies and Economics, 1-9. https://doi.org/10.9734/sajsse/2018/v2i225835

Tama, R. A. Z., Ying, L., Yu, M., Hoque, M. M., Adnan, K. M., \& Sarker, S. A. (2021). Assessing farmers' intention towards conservation agriculture by using the Extended Theory of Planned Behavior. Journal of Environmental Management, 280, 111654. https://doi.org/10.1016/j.jenvman.2020.111654

Tumwine, J. (2011). Implementation of the Framework Convention on Tobacco Control in Africa: Current Status of Legislation. International Journal of Environmental Research and Public Health, 8(11), 4312-4331. https://doi.org/10.3390/ijerph8114312

van Walbeek, C., \& Filby, S. (2019). Analysis of Article 6 (tax and price measures to reduce the demand for tobacco products) of the WHO Framework Convention on Tobacco Control. Tobacco Control, 28(Suppl 2), s97-s103. https://doi.org/10.1136/tobaccocontrol-2018-054462

Weingast, B. R., \& Wittman, D. A. (2009). The Reach of Political Economy (D. A. Wittman \& B. R. Weingast, Eds.; Vol. 1). Oxford University Press. https://doi.org/10.1093/oxfordhb/9780199548477.003.0001

Weingast, B. R., \& Wittman, D. A. (2011). Overview Of Political Economy. Oxford University Press. https://doi.org/10.1093/oxfordhb/9780199604456.013.0038

WHO. (2011). WHO report on the global tobacco epidemic 2011: Warning about the dangers of tobacco (The MPOWER Package) [Study Report]. World Health Organization. Retrieved from https://apps.who.int/tobacco/global_report/2011/en/index.html

WHO. (2015). Global Youth Tobacco Survey (GYTS), Bangladesh Report, 2013. World Health Organization, Regional Office for South-East Asia.

WHO. (2019). WHO global report on trends in prevalence of tobacco use 2000-2025 (Third). World Health Organization. Retrieved from https://www.who.int/publications/i/item/who-global-report-on-trends-inprevalence-of-tobacco-use-2000-2025-third-edition

World Bank. (2021). Bangladesh: An Overview [Country Overview]. The World Bank. Retrieved from https://www.worldbank.org/en/country/bangladesh/overview

Wu, F., Chen, Y., Parvez, F., Segers, S., Argos, M., Islam, T., Ahmed, A., Rakibuz-Zaman, M., Hasan, R., Sarwar, G., \& Ahsan, H. (2013). A Prospective Study of Tobacco Smoking and Mortality in Bangladesh. PLoS ONE, 8(3), e58516. https://doi.org/10.1371/journal.pone.0058516

\section{Notes}

Note 1 . The petitioner sued the government of Bangladesh for its failure to enforce a statutory warning to disclose tobacco's effects on health. The Court directed the government to undertake measures to restrict tobacco production and smoking in public and banned certain advertising and promotions of products. To avail the full judgment of the High Court, visit: https://www.tobaccocontrollaws.org/litigation/decisions/bd-20000207-voyage-of-discovery

Note 2. The global movement against tobacco led by WHO aims to create 'a tobacco-free world by 2040 - where less than $5 \%$ of adults use tobacco-is socially desirable, technically feasible, and could become politically practical' (Beaglehole et al., 2015, p. 1011) 
Note 3. Bidi is a thin cigarette filled with tobacco. It is relatively cheap and one of the major tobacco products consumed in Bangladesh. For more details, see (Rasheed \& Sinha, 2012).

Note 4. In Bangladesh, Secretary is the chief executive officer of a Ministry. The individual is a non-elected bureaucrat.

Note 5. The cost-of-illness approach was first used to study the economic costs of the health effects of smoking in 1984 (see Rice et al., 1986). Later WHO followed this approach in 2004 to estimate the economic costs of tobacco in Bangladesh. This method depends on three measuring components: (i) private expenditure, (ii) government expenditure, and (iii) Loss of productivity and income (Faruque et al., 2020, p. 10).

Note 6. Contract farming is a form of agreement between the farmers and tobacco businesses which allows the latter to control tobacco variety, volume, production costs, and creates asymmetric bargaining powers between tobacco firms and farmers (Hasan, 2020).

Note 7. MPOWER stands for - Monitor, Power, Offer, Warn, Enforce and Raise. For more details, visit: https://tobaccocontrolgrants.org/About-the-BI-Grants-Program.

Note 8. Over the past decade, Bloomberg Philanthropies has invested $\$ 1.1$ billion to fight tobacco use in low and middle-income countries. For more details, visit: https://www.bloomberg.org/public-health/reducing-tobacco-use/.

\section{Copyrights}

Copyright for this article is retained by the author(s), with first publication rights granted to the journal.

This is an open-access article distributed under the terms and conditions of the Creative Commons Attribution license (http://creativecommons.org/licenses/by/4.0/). 